\title{
Policy and institutional framework considerations in the implementation of catchment-based water resources management in Uganda: highlights from the River Rwizi catchment
}

\author{
P. Songa ${ }^{1}$, J. Rumohr ${ }^{2} \&$ R. Musota ${ }^{3}$ \\ ${ }^{1}$ Ove Arup \& Partners Ltd, UK, \\ ${ }^{2}$ Deutsche Gesellschaft für Internationale Zusammenarbeit (GIZ) GmbH, \\ Uganda \\ ${ }^{3}$ Directorate of Water Resources Management, \\ Ministry of Water and Environment (MWE), Uganda
}

\begin{abstract}
Water policy in Uganda has been based on the IWRM approach since the Water Action Plan was enacted in 1995. A water sector reform study in 2005 recommended moving to catchment-based water resources management. The River Rwizi catchment in south-western Uganda was selected as the pilot catchment for implementation. The catchment is a key source of water for municipal supply, agriculture, tourism and local industry, and frequently suffers water resource shortages. This paper assesses the existing policy and institutional framework, and whether it can support water stewardship initiatives or a catchment management plan. The paper examines the mandates, structure, roles and capacity of the institutions involved in water resources planning and development, within the context of existing national policy framework and the transition to catchment-based water resources management. The institutional structure broadly provides a suitable framework for implementation of national policies and regulations. However, there are areas of weakness which give rise to economic, environmental and regulatory water risk.

Keywords: water risk, water stewardship, policy, capacity, institutions, IWRM, catchment.
\end{abstract}




\section{Introduction}

Uganda has established a comprehensive national policy framework for the management of water resources in the country. This began with the 1995 Constitution and the Local Governments Act (1997). Below these sit a number of policies such as the National Water Policy (1999), the National Environmental Management Policy (1994), the National Policy for the Conservation of Wetlands (1995) and, more recently, the Climate Change Policy (draft, 2012). The policies articulate the Government's position and background to investment in each sector. The broad aspirations set out are translated into legal powers through Acts, Statutes and Regulations, such as the Water Act and accompanying regulations (i.e. the Water Resources Regulations (1998); the Waste Discharge Regulations (1998); the Water Supply Regulations (1999), and the Sewerage Regulations (1999)). The National Water \& Sewerage Corporation Act (2000) and Land Act (1998) are also important for water resources management. Policies and acts are supported in turn by national sector plans, for example the Uganda Water Action Plan (1995) and strategic plans such as the Agriculture Sector Development Strategy and Investment Plan 2010/11-2014/15. Institutions have been established for the implementation of policies at national level, with some functions, particularly those related to wetlands, the environment and water and sanitation decentralised to local (district) level. While 'water resources management' remains a function of the central government, it has now also been decentralised through the Water Management Zones (WMZs) along hydrological rather than political boundaries.

\section{Current WRM institutional framework}

\subsection{National water policy objectives}

The National Water Policy objectives are summarised below:

i. To manage and develop the water resources of Uganda in an integrated and sustainable manner, so as to secure and provide water of adequate quantity and quality for all social and economic needs of the present and future generations with the full participation of all stakeholders.

ii. Sustainable provision of safe water within easy reach and hygienic sanitation facilities, based on management responsibility and ownership by the users.

iii. To promote the development of water supply for agricultural production in order to modernise agriculture.

The policy objectives as currently framed appear to place emphasis on the protection and management of the resource, before development of the resource for social and economic needs. In practice, however, the main strategic and operational documents used within the water sector prioritise domestic water supply and sanitation. Water resources management issues are addressed to a limited degree at best. 


\subsection{Water management structure}

\subsubsection{National level}

The Ministry of Water (MWE) is responsible for setting national policies and standards, managing and regulating water resources and determining priorities for water development and management [1]. The ministry is also responsible for water sector development programmes delivered through three Directorates:

- The Directorate of Water Development (DWD) incorporates urban and rural water supply departments, the Water for Production department, the Department of Water Utility Regulation and a new Department for Water Sector Liaison.

- The Directorate of Water Resources Management (DWRM) incorporates the Water Resource Planning \& Management, Water Resource Monitoring \& Assessment and Water Quality departments. It also has a Department for International and Trans-Boundary Water Affairs.

- The Directorate of Environmental Affairs (DEA) incorporates Wetlands Management \& Forest Sector Support departments, as well as the Environmental Support Services unit.

There are five autonomous bodies under the MWE through which it discharges its mandate. These are:

- The National Water and Sewerage Corporation (NWSC) which is fully owned by the Government and operates in key towns as an autonomous water board with a distinct legal status under the NWSC Statute.

- The National Forestry Authority (NFA).

- The National Environmental Management Authority (NEMA).

- The Climate Change Department (CCD).

- The Uganda Meteorological Authority.

The Department of Finance and Administration and Department of Policy and Planning carry out administrative and planning functions. The current regulatory functions performed by the ministry are summarised in Table 1 .

\subsubsection{District (community) level}

For the most part, the functions of MWE are established at the district level through delegated officials. These include the District Water Officer (representing DWD), District Natural Resources Officer (representing DEA), District Environmental Officer (representing NEMA) and District Forestry Officer (representing NFA/Forest Sector Support department).

\subsubsection{Regional level}

Sitting between central government and district level, there is representation at WMZ (regional) level for DWRM (Senior Water Officer) and specifically for the Wetlands Management Department (Regional Wetlands Coordinator). The water supply and sanitation function (DWD) is also represented through the regional 
Table 1: MWE regulatory functions.

\begin{tabular}{|c|c|c|c|}
\hline Directorate & $\begin{array}{l}\text { Department } \\
\text { or Unit }\end{array}$ & $\begin{array}{l}\text { Regulatory } \\
\text { Function }\end{array}$ & Role and Activities \\
\hline DWRM & $\begin{array}{l}\text { Water } \\
\text { Resource } \\
\text { Planning and } \\
\text { Regulation } \\
\text { Department }\end{array}$ & $\begin{array}{l}\text { Regulating water } \\
\text { abstraction and } \\
\text { discharge of } \\
\text { wastewater into } \\
\text { the environment }\end{array}$ & $\begin{array}{l}\text { Water use allocation (abstraction and } \\
\text { waste water discharge), water service } \\
\text { regulation (drilling, construction, } \\
\text { dam safety and easement), } \\
\text { compliance monitoring and } \\
\text { enforcement of water laws, review of } \\
\text { water-related EIAs and disseminating } \\
\text { information. }\end{array}$ \\
\hline DWD & $\begin{array}{l}\text { Department of } \\
\text { Water Utility } \\
\text { Regulation }\end{array}$ & $\begin{array}{l}\text { Regulating the } \\
\text { entire urban water } \\
\text { and sanitation } \\
\text { sub-sector } \\
\text { (including } \\
\text { NWSC) }\end{array}$ & $\begin{array}{l}\text { Possible transformation in the } \\
\text { medium to long term into a structure } \\
\text { within MWE, or form the basis for an } \\
\text { Independent Regulator or part of one. } \\
\text { This depends on the final, long term } \\
\text { decisions on the mode of regulation. }\end{array}$ \\
\hline NEMA & $\begin{array}{l}\text { Department of } \\
\text { Environment } \\
\text { Monitoring and } \\
\text { Compliance }\end{array}$ & $\begin{array}{l}\text { Compliance and } \\
\text { enforcement of } \\
\text { the existing legal } \\
\text { and institutional } \\
\text { frameworks on } \\
\text { environmental } \\
\text { management in } \\
\text { Uganda }\end{array}$ & $\begin{array}{l}\text { Mandate covers both green and } \\
\text { brown issues of environmental } \\
\text { management. It oversees the } \\
\text { implementation of all environment } \\
\text { conservation programmes and } \\
\text { activities of the relevant agencies at } \\
\text { the national and local Government } \\
\text { level. }\end{array}$ \\
\hline
\end{tabular}

Technical Support Units (TSU), Water and Sanitation Development Facility (WSDF) and other umbrella organisations e.g. South Western Umbrella Organisation.

Although not operational in all districts, the NWSC is represented by an area office in the towns and districts in which they operate. The CCD is the only body under the MWE which at the time of the research was not directly represented at district or regional level. Non-governmental organisations (NGOs) and community-based organisations (CBOs) are coordinated through the Uganda Water and Sanitations Network (UWASNET) secretariat which is located at national level. In addition, Water User Committees /Associations (WUC/A) are active at both national and district level. Figure 1 [2] shows the institutional setup in the water sector, including responsibility and accountability.

The structure shown provides an office at regional or district level to manage the various water-related sectors. The one function conspicuous by its absence is to do with land. The 'Lands' function was transferred from what was then Ministry of Water, Lands and Environment to the Ministry of Lands, Housing and Urban Development (MLHUD) in 2007. At the district level, District Land Boards and District Land (Management) Officers represent the central government. 


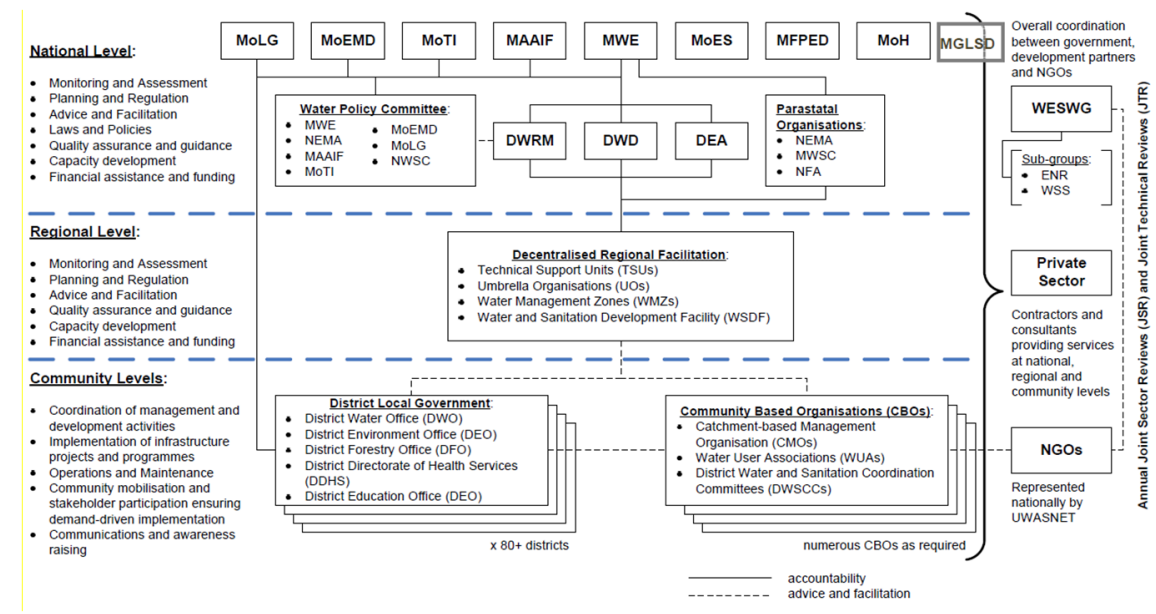

Figure 1: Water sector institutional setup [2].

\subsubsection{Inter-ministerial framework}

The MWE's mandate includes activities that link into other ministries' mandates. The clearly-identified cross-cutting mandates are:

- Development of public sanitary facilities and promotion of good practices of hygiene and sanitation in small towns and rural growth centres (for which there is a Memorandum of Understanding with the Health and Education \& Sports ministries).

- Lead agency with respect to water for production and development of offfarm facilities such as valley tanks (The Ministry of Agriculture (MAAIF) is the lead agency for water use and management for agricultural development on-farm).

In practice, however, there is a lack of clarity leading to overlap and potential for conflict with other ministries. Notably, there are significant water-related responsibilities being executed under the mandate of other ministries, which fall under the umbrella of "managing and regulating water resources and determining priorities for water development and management". For example, the mandate of the Ministry of Trade, Industry and Cooperatives (MTIC) includes "water use and management of industries, commerce, wildlife and tourism". Similarly, the mandate of the Ministry of Energy and Minerals (MEM) is "water use and management for hydropower generation". The above mandates in principal already fall within the water ministry's remit for managing and regulating water resources, and could potentially cause conflict of interest. In anticipation of such situations arising, an Inter-Ministerial Steering Committee (IMSC), which is set out in the National Water Policy. In practice, however, the committee does not appear to be providing the required coordination between the various ministries. A recent Policy Brief by the UNDP-UNEP Poverty-Environment Initiative notes that, although the IMSC is charged with handling cross-sectoral issues and 
situations of competition for water resources and the mandate to focus on the interactions between water, the environment, economy and society, and the situations of conflict and overuse that may arise, little work has been done to institutionalise joint action for water resources management. The document concludes that the need for joint investments in water supply and ecosystem maintenance has never been presented by committee for consideration, despite the relationship between water supply and ecosystem health becoming clear.

\section{Institutional and capacity challenges and issues}

Following the review of the existing water management framework, a literature review was carried out to identify the challenges and issues within the framework. This covered both the institutional setup and capacity. The efforts by the Government to put in place a suitable enabling environment for the proper management of the Uganda's water resources are clear from the preceding section of this paper. The literature review identified many challenges which have continue to lead to a lack of positive impact on the ground. Studies carried out by others into the broader environmental sector highlight the same or similar challenges.

\subsection{Challenges and gaps at central government level}

Perhaps the most significant challenge identified through the study is related to the implementation of the Ministry of Water's mandate through the various departments. The review strongly suggests that this often occurs in parallel, with little or no interaction, consultation, agreement or co-financing occurring between the directorates or departments throughout the conception, delivery and operation of water sector schemes. A review of the Uganda water sector carried out in 2012 by Grontmij [3] acknowledges the importance of the Water for Production (WfP) programme in achieving improved livelihood for communities in the rural areas, noting that the WfP department has managed to construct "hundreds of water infrastructure in an effective manner". However, Grontmij notes, the planning of such investments has been carried out "with limited consultation and involvement of other departments, stakeholders and communities". On water resources management in particular Grontmij observes: "A holistic approach to Water Resources Management is not fully embedded into the processes and procedures being followed. A focus on delivery has been dominant - Forced Account approach - whereas a pro-poor focus and environmental sustainability have not been given sufficient priority. There is need for institutional review and strengthening for improved coordination between DEA, NEMA, NFA and district local governments in policy implementation and regulation of natural resources and environment management."

The National Development Plan 2010-2015 is more direct, listing the constraints to the performance of the water resources management sector in Section 8.6.2. 
- Limited institutional and human capacity, especially skills in negotiating trans-boundary issues, regulating the use and pollution of water resources, and implementing catchment-based water resources management.

- Interference in the management of water resources, especially in regulatory aspects.

- Weak enforcement of laws and regulations for water abstraction releases and waste discharge.

- Lack of water resources data and information which limits analysis, negotiation on trans-boundary issues, proper management of the resources and community participation.

- Delayed implementation of land use policy.

Other research points to broader environmental conservation being much lower priority when held up against other needs competing for finances; this often leads to uncertain government commitment to environmental conservation. It is not uncommon for budget allocations to the environment sector to be reduced by $25 \%$ or greater during disbursement. Bintoora [4] offers a perspective which suggests that the underlying issue is a lack of political will: "Weak enforcement of the necessary conservation laws and regulations. The political will to support relevant institutions mandated to enforce the laws, regulations and bye-laws is also weak, perhaps due to the problem of conflicts of interests and the fear by local politicians to lose votes during future elections".

From the foregoing, it is apparent that there are gaps in implementation, as well as shortcomings in funding, administration and support of environmental management, including water resources management. Rwakakamba [5] suggests also that there are also critical problems in how the Government demonstrates responsible ownership, commitment, and strictness in applying the law on the environment. He identifies a gap in environmental law to the extent that most laws and policies are conservationist in nature, and do not include provisions for already depleted environmental resources to be restored their former state.

\subsection{Challenges and gaps at local government level}

The structures and roles required for effective natural resources management at the district level are largely in place, but there are capacity limitations. These are mainly around:

- Limited funding which restricts the capacity of the districts to promote sustainable land management and biodiversity conservation initiatives.

- Inadequate staffing in the environment and natural resources management departments, and lack of skilled staff.

- Lack of bye-laws, coupled with poor policy and law enforcement by the districts. This is exacerbated by political interference in policy implementation and law enforcement.

- Lack of harmony of structures in all districts e.g. environment committees that are important in implementation and management of interventions are in place in some districts but missing in others. 
- $\quad$ Lack of true cross-sector and water sector coordination. At present there are parallel implementation plans for water supply and sanitation, water for production and water resources management despite the plans relying on the same resources.

\section{Recent developments in water management at district level}

Following the completion of the Water Sector Reform Study in 2005, a Joint Sector Review (JSR) carried out in 2006 identified that the policy cooperation and effectiveness that had been anticipated were not being fully realised. Therefore, MWE developed further guidelines in 2009 for delivering water and sanitation at the district level. In addition, the Gender Strategy for the sector, which was originally developed and implemented between 2003 and 2008, was also revised in 2009. Nevertheless, there are key differences in how water supply and sanitation is implemented at local government (district) level, compared to water resources management.

\subsection{Water supply and sanitation}

DWD developed water and sanitation technical and non-technical guidelines to aid the districts in implementing water and sanitation programmes (new guidelines were still being developed and issued at the time the research was carried out). One such example is the MWE Sectoral Specific Guidelines, which require a technical committee - the District Water and Sanitation Coordination Committee (DWSCC) - to be appointed. The primarily role of the DWSCC is managing water and sanitation in the district; this includes co-ordination, planning and implementation of water and sanitation activities, as well as overseeing the implementation of 'water sector' activities. The committee includes a range of representatives, but none with a water resources function. Furthermore, the urban water supply and sanitation sub-sector is represented at regional level by a Technical Support Unit (TSU). However, the DWSCC and TSU's carry no explicit water resources management functions at present and have limited technical and planning interaction with DWRM staff.

\subsection{Water resources management}

There has been growing recognition in recent years of the importance of the broad aspects of water resources planning and management. In response, DWRM has also developed a suite of guidelines and frameworks (many of which are still in draft form) to aid water resources management in an integrated manner at the lowest appropriate level (i.e. the river basin). The main vehicle for integration of water resources management at district level is the "Guidelines for Catchment Based Water Resource Planning in Uganda", although the document was still in development by early 2014.

In 2006, the Government moved some of the responsibilities and functions previously carried out at the central level by DWRM to new units located in newlydefined Water Management Zones [6]. These are typically based in a regional 
headquarters e.g. Mbarara for the Victoria WMZ. Responsibility for policy and legislation, national water strategy, day-to-day coordination at central level, transboundary waters and technical backstopping of the zonal offices remains with DWRM. It is expected that when fully implemented, the focus on solving problems faced in each individual zone and catchments would improve. The catchment guidelines are, therefore, meant to provide a common framework for WMZ teams to operate, and are currently being assessed in the River Rwizi catchment. In addition, a series of documents which provide a framework for water source protection were developed in 2013. They are intended to provide a comprehensive framework for water resources management at district level. The documents are applicable to non-governmental bodies and are meant to be used by anyone with a responsibility for a piece of water infrastructure. If utilised, these documents are likely to complement the catchment planning guidelines and provide suitable water resources management guidance to district and regional water supply practitioners (e.g. TSUs and DWOs) and they should be actively encouraged to use them.

\section{A brief overview of institutional arrangements and partnerships in the River Rwizi catchment}

The River Rwizi catchment in south-western Uganda served as the pilot catchment for the implementation of "participatory, decentralised IWRM" between 2006 and 2009. The pilot study identified two important requirements:

- An IWRM coordinator stationed in the catchment is essential for successful implementation of IWRM. This is the Team Leader role, and is a visible point of contact within the WMZ for all stakeholders in that catchment. For the Rwizi catchment the Team Leader role is currently fulfilled by the Senior Water Officer (Victoria WMZ).

- Using existing institutional structures, complemented by a few new structures, is a more efficient way to implement IWRM processes.

The proposed structure [6] within which catchment-based WRM will be implemented is shown in Figure 2.

For the River Rwizi catchment, both the management organisation (CMO) and management committee (CMC) have been in place since 2013, when a three-year partnership between MWE, German Development Cooperation and The CocaCola System was set up to support the existing catchment management structures. The partnership has supported the institutionalisation of the CMO in the Rwizi catchment. As a result the CMC is active and meets regularly, despite lack of formal government support or a clear funding stream. It is paramount that formalisation of funding for their activities is achieved. The commissioning of a water risk assessment funded by the partners supports the CMC's activities and demonstrates its ability to discharge its responsibility, as well as its visibility and influence within the WMZ. Despite the above achievements, some of the previously-identified higher level institutional challenges were observed within the catchment organisational set up. For example: 


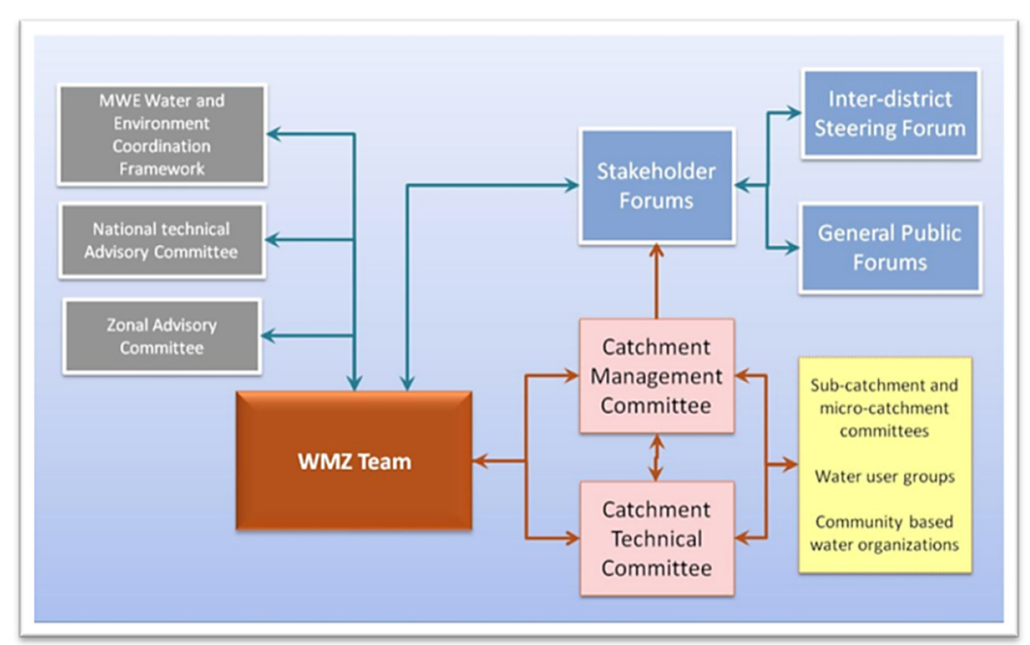

Figure 2: Catchment management organisation links.

- Disparity in who represents a district on the CMC (e.g. natural resources officer, administrative officer, marketing officer, water officer).

- Interviews carried out with selected staff in Mbarara district largely supported Grontmij's view of fragmentation in the water sector, and the need for improved coordination in policy implementation and natural resource regulation.

- An apparent bias towards water supply and sanitation issues at district level, with very little evidence of knowledge of water resources management issues; this applies to water sector in Uganda as whole.

\subsection{Institutional framework and water risk in the River Rwizi catchment}

The water risk assessment identified institutional issues which are likely to have a significant influence on how water-related risk develops or is addressed in a river catchment. Many of the problems identified relate to ineffective implementation of national policy and regulation, and will require high level government attention to resolve. Successful resolution should strengthen the probability of success in establishing catchment-based water resources management countrywide. The key points relating to water risk are summarised in Table 2, together with proposed institutional and regulatory actions.

The following recommendations are also made:

- Guidance on water user financing of water resources should be written into the CPG, as has been done with the Water Sector Guidelines (2009) for water supply.

- Variations to licence conditions should be explored, to replace the current flat rates e.g. including seasonal flow rules, varying the location of proposed monitoring stations, etc. so that the licence conditions reflect local circumstances better. 
Table 2: Water sector institutional framework actions to reduce water risk.

\begin{tabular}{|c|c|}
\hline Current Status & $\begin{array}{c}\text { Action Required to Reduce } \\
\text { Water Risk }\end{array}$ \\
\hline $\begin{array}{l}\text { There is no provision in the draft Catchment Planning } \\
\text { Guidelines for the CMC/CMO to consent to or comment } \\
\text { on abstraction or discharge permits. For transparency, } \\
\text { equitable sharing of resources and pain/gain share by all } \\
\text { stakeholders, it is necessary that the CMO has the power } \\
\text { to object to a permit application if there is evidence that } \\
\text { it will significantly impact on the health of the } \\
\text { catchment and adequate mitigation is not proposed. This } \\
\text { will ensure that the stakeholders are able to influence } \\
\text { the use of water resources in the catchment. It will also } \\
\text { encourage new water users to work with the CMO from } \\
\text { the outset. }\end{array}$ & $\begin{array}{l}\text { The current water and } \\
\text { wastewater permitting system } \\
\text { needs to be reformed to take } \\
\text { account of recent changes to } \\
\text { the water resources } \\
\text { management framework. It } \\
\text { also needs to build in } \\
\text { consideration for local } \\
\text { catchment circumstances. }\end{array}$ \\
\hline $\begin{array}{l}\text { The respective permit fees were established in } 1998 \\
\text { under the Water Regulation and the Water (Waste } \\
\text { Discharge) Regulations, and have not been changed to } \\
\text { date. There are a number of issues with the current } \\
\text { approach: fees have not kept up with inflation and other } \\
\text { economic factors, they do not take into account the } \\
\text { prevailing state of the environment and are applied as } \\
\text { flat rates across all catchments. }\end{array}$ & $\begin{array}{l}\text { Water sector permits need to } \\
\text { be updated, taking into } \\
\text { account the issues identified. } \\
\text { It is recognised good practice } \\
\text { to include the costs of water } \\
\text { management in a catchment } \\
\text { within charges paid by users } \\
\text { in the catchment. }\end{array}$ \\
\hline
\end{tabular}

\section{Conclusions}

The institutional and capacity issues identified in this study are by no means new, and have been highlighted in other studies into decentralised management of natural resources, environmental protection and conservation functions. Where interventions have been implemented, they have either not realised their intended benefits, or the outcomes have varied from one catchment to the other.

Water resources management is of particular concern due to a lack of institutional and technical capacity at local levels. However, the most serious institutional and capacity challenges that need to be overcome relate to poor cooperation and coordination among water sector practitioners, poor sensitisation of stakeholders, inadequate funding of activities, poor accountability by local leaders, and lack of political support. In some cases instead of generating greater participation of local government, decentralisation has enabled local political interest to control natural resources. Weaknesses in implementing environmental protection laws and policies and political interference are also commonly cited as key limitations in conservation efforts. Existing institutional structures generally provide a suitable structure for implementation of the policies and regulations. However, improved water resources management requires greater clarity with regard to prioritisation of water needs, improved coordination amongst the water sector institutions in order to realise joint opportunities and efficiencies, and more effective implementation and enforcement of regulation. 


\section{Acknowledgements}

The support of the International Water Stewardship Programme (IWaSP), a programme of the German Development Cooperation and the UK Department for International Development (DFID) is acknowledged. The views in this paper represent the opinion of the authors and do not reflect the views or position of GIZ $\mathrm{GmbH}$.

\section{References}

[1] Ministry of Water and Environment (MWE), www.mwe.go.ug

[2] MWE, Strategic Sector Investment Plan for the Water and Sanitation Sector in Uganda, p. 8, 2009.

[3] Grontmij, Technical Support to Joint Appraisal of the Joint Water and Environmental Sector Support Programme (JWESSP), Uganda, Final Appraisal Report, pp. 15-16, 2012.

[4] Bintoora, K. K., The Assessment of Generic Management Efforts to Address the Effects of Poor Land Use Practices in Lake Nakivale Wetland System in Isingiro District, Uganda. Acad. J. Environ. Sci. 1(7): pp. 130-146, 2013.

[5] Rwakakamba, M.T., How Effective Are Uganda's Environmental Policies? A Case Study of Water Resources in 4 Districts With Recommendations on How to Do Better, Mountain Research and Development (MRD) 29(2), International Mountain Society, pp. 121-127, 2009.

[6] MWE, Guidelines for Catchment Based Water Resources Planning in Uganda, Working Draft v7, pp. 4-11, 2012. 